\title{
Pengaruh Model Pembelajaran Kooperatif Tipe Pair Checks terhadap Hasil Belajar Fisika Siswa Kelas VIII SMP Negeri Model Terpadu Madani
}

\author{
Rasni Kikot, Yusuf Kendek, dan I Komang Werdhiana \\ Rasnikikot.2012@gmail.com \\ Program Studi Pendidikan Fisika FKIP Universitas Tadulako \\ Jl. Soekarno Hatta Km. 9 Kampus Bumi Tadulako Tondo Palu - Sulawesi Tengah
}

\begin{abstract}
Abstrak - Penelitian ini bertujuan untuk mengetahui ada tidaknya pengaruh model pembelajaran kooperatif tipe pair checks terhadap hasil belajara fisika siswa. Jenis penelitian ini merupakan kuasi eksperimen dengan desain Postest-Only Comparison Group Design. Populasi penelitian adalah siswa kelas VIII SMP Negeri Model Terpadu Madani. Pengambilan sampel dilakukan secara purposive sampling dengan sampel penelitian adalah kelas VIII Taufik Ismail sebagai kelas eksperimen dan kelas VIII Ki Hajar Dewantara sebagai kelas kontrol. Instrumen penelitian berupa tes hasil belajar yang telah divalidasi oleh validator ahli. nilai rerata untuk kelas eksperimen adalah 8,92 dan nilai rerata kelas kontrol adalah 7,67. Hasil uji normalitas posttest diperoleh $X^{2}$ hitung untuk kelas eksperimen yaitu 2,55 dan kelas kontrol yaitu 4,83 dan nilai $X^{2}$ tabel yaitu 5,99. Hasil uji homogenitas untuk kelas eksperimen yaitu 4,34 dan untuk kelas kontrol yaitu 3,96, F tabel yaitu 2,05. Hasil uji hipotesis diperoleh nilai thitung sebesar 2,16 dan nilai tabel pada taraf signifikansi 5\% dan dk=43 yaitu 2,02. Hasil ini menunjukkan bahwa terdapat perbedaan hasil belajar fisika siswa antara kelas eksperimen dan kelas kontrol. Sehingga Dapat disimpulkan bahwa terdapat pegaruh model pembelajaran kooperatif tipe pair checks terhadap hasil belajar fisika siswa kelas VIII SMP Negeri Model Terpadu Madani.
\end{abstract}

Kata Kunci: pembelajaran kooperatif tipe pair checks, hasil belajar fisika

\section{PENDAHULUAN}

Hasil belajar siswa merupakan hal yang paling diperhatikan pada proses belajar mengajar, hal itu menyebabkan banyak model pembelajaran yang diterapkan pada siswa untuk meningkatkan hasil belajar mereka. Apalagi pada mata pelajaran fisika, banyak siswa yang sulit untuk memahaminya, oleh karena itu dibutuhkan model pembelajaran yang cocok untuk meningkatkan hasil belajar siswa.

Model pembelajar kooperatif merupakan salah satu model pembelajaran yang banyak digunakan untuk meningkatkan hasil belajar siswa. model pembelajaran koperatif memiliki banyak tipe, salah satunya adalah model pembelajaran kooperatif tipe pair checks yang dapat meningkatkan hasil belajar siswa.

Strategi pengajaran pemecahan masalah menggunakan kelompok pembelajaran koperatif adalah efektif bagi prestasi siswa pada ilmu fisika [1]. Pembelajaran kooperatif memiliki beberapa tipe. Pada penelitian ini digunakan tipe pair checks. Pada model pembelajaran kooperatif tipe pair checks ini siswa dibagi dalam kelompokkelompok dan satu kelompok terdiri terdiri dari dua orang saja.

Model pembelajaran kooperatif tipe pair checks ini merupakan salah satu cara untuk membantu siswa yang pasif dalam kegiatan kelompok, mereka melakukan kerja sama secara berpasangan dan menerapkan susunan pengecekan berpasangan [2]. Model pembelajaran kooperatif tipe pair checks dapat meningkatkan kerja sama siswa dalam memecahkan masalah juga mengajarkan siswa saling menghargai dan membantu siswa yang kurang [3]. Pembelajaran kooperatif tipe pair checks dapat meningkatkan tingkat pemahaman siswa dalam kursus [4].

Model pembelajaran kooperatif tipe pairs checks pemecahan masalah dapat meningkatkan social skill siswa [5]. Model pembelajaran kooperatif Pair Checks memberikan efek positif pada siswa seperti membuat siswa belajar mengajari yang lain, berbagi apa yang mereka pikirkan kepada siswa lain, memotivasi siswa lain untuk belajar dan memberikan penghargaan kepada diri mereka sendiri dalam bekerjasama [6].

Berdasarkan uraian diatas tampak bahwa, model pembelajaran kooperatif tipe pair checks berpengaruh terhadap kemampuan siswa melalui pemahaman siswa dan sosial skill siswa. Karena itu perlu juga diteliti pengaruh model pembelajaran kooperatif tipe pair checsk terhadap hasil belajar. 
p-ISSN 2338-3240, e-ISSN 2580-5924

\section{METODE PENELITIAN}

Jenis penelitian ini adalah kuasi eksperimen dengan desain penelitian menggunakan "PostestOnly Comparison Group Design Desain penelitian ini digambarkan pada Tabel 1. [7]

TABEL 1 DESAIN PENELITIAN

\begin{tabular}{lcc}
\hline \multicolumn{1}{c}{ Kelas } & Perlakuan & Posttest \\
\hline Eksperimen & $\mathrm{X}_{1}$ & $\mathrm{O}$ \\
Kontrol & - & $\mathrm{O}$ \\
\hline eterangan : & & \\
$\mathrm{X}_{1}$ & : model pembelajaran kooperatif tipe pair checks \\
pembelajaran konvensional model direct & instruction \\
: tes awal sama dengan tes akhir &
\end{tabular}

Penelitian dilakukan di SMP Negeri Model Terpadu Madani. Populasi dalam penelitian ini adalah seluruh siswa kelas VIII SMP Negeri Model Terpadu Madani tahun pelajaran 2016/2017 yang terdiri dari 5 kelas. Sampel dalam penelitian ini adalah kelas VIII Taufik Ismail yang berjumlah 24 siswa dan VIII Ki Hajar Dewantara yang berjumlah 21 siswa. Teknik pengambilan sampel yang digunakan adalah purposive sampling, yaitu teknik penentuan sampel dengan pertimbangan tertentu.

Instrumen yang digunakan dalam penelitian ini adalah tes pilihan ganda yang telah divalidasi oleh validator ahli dan telah diuji cobakan di kelas VIII yang sudah pernah diajarkan materi getaran dan gelombang yaitu di kelas VIII Chairil Anwar. Analisis data hasil penelitian menggunakan uji normalitas, ujii homogenitas dan uji hipotesis ( $u j i-t)$.

\section{HASIL DAN PEMBAHASAN}

\section{A. Hasil Penelitian}

Pada penelitian ini proses validasi dilakukan oleh validator ahli. Dimana soal yang telah dibuat dikonsultasikan kepada validator ahli. Instrumen soal yang dibuat berjumlah 23 soal, kemudian berdasarkan hasil validitas ahli disetujui 20 soal yang selanjutnya dilakukan uji coba soal pada kelas yang sudah pernah diajarkan materi getaran dan gelombang, berdasarkan kreteria validitas soal, daya beda soal, tingkat kesukaran soal dan realibilitas soal terdapat 12 soal yang memenuhi kreteria, yang akan digunakan sebagai soal postest pada siswa kelas VIII SMP Negeri Model Terpadu Madani.

Berdasarkan hasil pemberian posttest pada kelas eksperimen yang berjumlah 24 siswa dan kelas kontrol yang berjumlah 21 siswa diperoleh nilai maksimum, nilai minimum, nilai rata-rata dan simpangan baku seperti terlihat pada Tabel 2.
TABEL 2 DESKRIPSI SKOR TES HASIL BELAJAR UNTUK KELAS EKSPERIMEN

\begin{tabular}{|c|c|c|}
\hline \multirow{2}{*}{ Uraian } & \multicolumn{2}{|c|}{ Posttest } \\
\hline & Fkcnerimen & Kontrol \\
\hline Sampel (n) & 24 & 21 \\
\hline Nilai maksimum & 12 & 12 \\
\hline Nilai minimum & 4 & 4 \\
\hline Skor rata-rata & 8,92 & 7,67 \\
\hline Standar deviasi & 4,34 & 3,96 \\
\hline
\end{tabular}

Hasil perhitungan analisis uji normalitas Posttest dapat dilihat pada Tabel 3.

TABEL 3 HASIL UJI NORMALITAS POSTTEST KELAS EKSPERIMEN DAN KELAS

\begin{tabular}{|c|c|c|}
\hline \multirow{2}{*}{ Uraian } & \multicolumn{2}{|c|}{ Posttest } \\
\hline & Eksperimen & Kontrol \\
\hline Nilai $\chi^{2}$ hitung & 2,55 & 4,83 \\
\hline Nilai $\chi^{2}$ tabel & 5,99 & 5,99 \\
\hline Keputusan & $\begin{array}{c}\text { Terdistribusi } \\
\text { normal }\end{array}$ & $\begin{array}{l}\text { Terdistribusi } \\
\text { normal }\end{array}$ \\
\hline
\end{tabular}

Berdasarkan hasil uji normalitas pada tabel 3 dengan derajat kebebasan $\mathrm{dk}=\mathrm{k}-3=5-3=$ 2 dengan peluang $(1-\alpha)=1-0,05=0,95$ pada taraf signifikansi $\alpha=0,05$, diperoleh nilai $X^{2}$ Hitung untuk postest kelas eksperimen dan kontrol masing-masing 2,55 dan 4,83 dengan $X^{2}$ tabel 5,99 sehingga $X^{2}$ Hitung $<X^{2}$ tabel. Sesuai kriteria pengambilan keputusan, maka data posttest dari kelas eksperimen maupun kelas kontrol keduanya berasal dari populasi yang terdistribusi normal.

Hasil perhitungan analisis uji homogenitas postest dapat dilihat pada Tabel 4 .

TABEL 4 HASIL UJI HOMOGENITAS POSTEST

\begin{tabular}{cc}
\hline Uraian & Posttest \\
\hline Nilai F Hitung & 1,10 \\
Nilai $F$ tabel $(a=0,05)$ & 2,05 \\
Keputusan & Homogen \\
\hline
\end{tabular}

Berdasarkan hasil uji homogenitas pada tabel 4, dengan derajat kebebasan untuk pembilang $\left(n_{1}\right)=24$ dan penyebut $\left(n_{2}\right)=21$ pada taraf signifikansi $\alpha=0,05$, maka nilai $F_{\text {tabel }}$ diperoleh sebesar $F_{0,05(24,21)}=2,05$ dan nilai ini lebih besar dari nilai Fhitung nilai postest yaitu 1,10 . Berdasarkan kriteria pengambilan keputusan, diketahui data tersebut memiliki varians yang sama atau homogen.

Hasil perhitungan analisis uji beda rata-rata (dua pihak) Postest dapat dilihat pada Tabel 5.

TABEL 5. UJI BEDA RATA-RATA (SATU PIHAK) POSTEST KELAS EKSPERIMEN

\begin{tabular}{|c|c|c|c|c|c|}
\hline No & kelas & $\bar{X}$ & T hitung & $\begin{array}{l}\mathrm{T} \\
\text { tabel }\end{array}$ & Keputusan \\
\hline 1 & $\begin{array}{l}\text { Kelas } \\
\text { eksperi } \\
\text { men }\end{array}$ & 8,92 & 2,16 & 2,02 & $\mathrm{H}_{1}$ diterima \\
\hline 2 & $\begin{array}{l}\text { Kelas } \\
\text { kontrol }\end{array}$ & 7,67 & & & \\
\hline
\end{tabular}


Berdasarkan data Tabel 5 dan kriteria pengujian dimana $H_{0}$ ditolak jika $t \geq t_{(1-1 / 2 a)}$ dapat dilihat nilai thitung berada di luar daerah penerimaan $\mathrm{H}_{0}$. Dengan demikian $\mathrm{H}_{0}$ ditolak dan $\mathrm{H}_{1}$ diterima. Dengan kata lain, rata-rata skor hasil belajar fisika siswa yang belajar dengan model pembelajaran kooperatif tipe pair checks lebih besar dari rata-rata skor hasil belajar fisika siswa yang belajar dengan model pembelajaran direct instruction. Sehingga dapat disimpulkan bahwa siswa pada kelas eksperimen dan kelas kontrol memiliki kemampuan akhir yang berbeda.

\section{B. Pembahasan}

Kegiatan pembelajaran pada penelitian ini, dilakukan sebanyak 4 kali pertemuan yang terdiri dari 3 kali tatap muka di kelas dan 1 kali pertemuan untuk posttest dikedua kelas baik itu di kelas kontrol maupun di kelas eksperimen. Pada tes akhir (posttest) diberikan untuk mengetahui kemampuan akhir siswa di kedua kelas dan sebagai data analisis penelitian yang selanjutnya digunakan sebagai pembanding untuk melihat apakah terdapat perbedaan hasil belajar antara kedua kelas tersebut terkait materi getaran dan gelombang. Tes yang digunakan dalam penelitian ini yaitu tes pilihan ganda berjumlah 12 nomor.

Hasil analisis posttest menunjukkan bahwa perolehan nilai rata-rata untuk kelas ekperimen adalah 8,92 dan untuk kelas kontrol diperoleh nilai rata-rata yaitu 7,67 . Data posttest berdistribusi normal dan memiliki varians yang homogen, kemudian dilakukan uji hipotesis (menggunakan uji dua pihak) dan didapatkan hasi bahwa terdapat perbedaan hasil belajar antara kelas ekperimen dan kelas kontrol.

Hasil uji coba normalitas posttest diperoleh nilai $X^{2}$ hitung untuk kelas ekperimen yaitu 2,55 dan kelas kontrol yaitu 4,83 dan nilai $X^{2}$ tabel yaitu 5,99 . Hasil tersebut menunjukkan bahwa nilai $X^{2}$ hitung lebih kecil dari pada nilai $X^{2}$ tabel sehingga keduanya berasal dari populasi yang terdistribusi normal.

Hasil uji coba homogenitas dua varians posttest kelas ekperimen diperoleh nilai varians 4,34 dan untuk kelas kontrol yaitu 3,96 sedangkan varians hitung yaitu 1,10 , nilai $F$ tabel yaitu 2,05. Berdasarkan hasil tersebut dengan taraf signifikan $(\alpha=0,05)$ diperoleh bahwa Fitung lebih kecil dari $F_{\text {tabel }}$ maka berdasarkan kriteria pengambilan keputusan dapat disimpulkan bahwa tidak terdapat perbedaan varians antara kelas ekperimen dan kelas kontrol atau dengan kata lain varians antara kelas kontrol dan kelas ekperimen adalah sama atau homogen.

Berdasarkan uji hipotesis yang telah dilakukan diperoleh nilai $t_{\text {hitung }}=2,16$ dan $t_{\text {tabel }}=2,02$.
Karena nilai $t_{\text {hitung }}>t_{\text {tabel }}$, taraf signifikasi $\alpha=$ 0,05 maka $\mathrm{H}_{0}$ ditolak atau $\mathrm{H}_{1}$ diterima. Sehingga dapat disimpulkan bahwa ada perbedaan hasil belajar fisika siswa yang menggunakan model pembelajaran kooperatif tipe pair checks dengan model pembelajaran konvensional pada siswa kalas VIII SMP Negeri Model Terpadu Madani

Hasil belajar fisika kelompok eksperimen yang menggunakan model pembelajaran kooperatif tipe pair checks memiliki hasil belajar lebih tinggi dibandingkan dengan kelas kontrol yang menggunakan model pembelajran konvensional. Karena pada kelas kontrol ini keaktifan guru lebih dominan dibandingkan keaktifan siswa, sehingga siswa hanya mendengarkan dan menulis penjelasan yang diberikan oleh guru. Sedangkan pada kelas eksperimen, diberikan pembelajaran dengan model pembelajaran kooperatif tipe pair checks. Hal ini disebabkan karena dengan menggunakan model pembelajaran kooperatif tipe pair checks siswa akan dituntut untuk lebih aktif sedangkan guru hanya bertindak sebagai fasilitator yang membantu siswa jika mendapat kesulitan saat pembelajaran berlangsung.

Tahap-tahap model pembelajaran kooperatif tipe pair checks yang digunakan pada kelas ekperimen terdiri dari 5 tahap yaitu pendahuluan, pair, checks, diskusi kelompok, penghargaan.

Tahap pertama, yaitu guru menyajikan materi, menyiapkan siswa untuk melakukan pembelajaran menggunakan model pembelajaran kooperatif tipe pair checks, menuntun siswa dalam pembentukan kelompok, memberikan lembar kerja siswa (LKS) kepada semua siswa, membimbing siswa untuk mengerjakan lembar kerja siswa. Tahap pertama ini guru mendominasi hampir semua kegiatan didalam kelas. Tahap kedua (pair), siswa berpasangan dengan teman sebangkunya, setiap pasangan dalam satu kelompok memiliki peran yang berbeda, yaitu pelatih dan partner. Tahap ketiga (checks), tahap ini partner menjawab soal sedangkan pelatih akan mengecek jawabannya. Partner yang menjawab satu soal dengan benar berhak mendapatkan satu point dari pelatih. Pelatih dan partner saling bertukar peran, pelatih menjadi partner, partner menjadi pelatih, setelah itu setiap pasangan kembali kekelompok awal dan saling mencocokan jawaban.

Tahap keempat, yaitu diskusi kelompok pada tahap ini siswa berdiskusi dengan kelompoknya mengenai jawaban dari pertanyaan pada lembar kerja siswa (LKS) yang telah dkerjakan secara individu. Pada tahap ini juga terjadi interaksi antara guru dangan siswa dan siswa dangan siswa, mulai dari guru meminta beberapa siswa perwakilan tiap kelompok untuk 
p-ISSN 2338-3240, e-ISSN 2580-5924

mempersentasikan jawaban, memberikan kesempatan kepada siswa dari kelompok lain untuk bertanya atau menanggapi, guru membimbing dan memberikan arahan atas jawaban dari barbagai soal, setelah itu setiap kelompok mengecek jawabannya. Tahap kelima (penghargaan), pada tahap ini guru memberikan hadiah atau reward kepada kelompok yang paling banyak mendapatkan poin. Hal ini yang membuat siswa lebih memahami dengan benar materi pelajaran yang diajarkan.

Berbeda dengan kelas kontrol, model pembelajaran yang diterapkan yaitu pembelajaran konvensional dengan model direct instruction sebagai pembanding kelas eksperimen yang menggunakan model pembelajaran kooperatif tipe pair checks, siswa dalam kegiatan pembelajaran konvensional ini kurang aktif dalam kegiatan pembelajaran, hal ini menyebabkan banyak siswa yang bermain dalam kelas pada saat pembelajaran berlangsung sehingga siswa tidak menyimak dengan baik penjelasan materi yang diberikan guru.hal ini juga berpengaruh pada hasil belajar siswa karena siswa secara aktif dan kreatif dalam proses pembelajaran yang seharusnya siswa lebih berperan aktif.

Hasil yang diperoleh pada penelitian ini menunjukkan bahwa hasil belajar fisika siswa yang diajarkan model pembelajaran kooperatif tipe pair checks lebih tinggi dibandingkan dengan hasil belajar fisika siswa yang diajarkan dengan model pembelajaran konvensional. Hasil ini sesuai dengan hasil penelitian Komara, S (2010) hasil penelitian mengungkapkan bahwa model pembelajaran kooperatif tipe pair checks berpengaruh terhadap hasil belajar matematika siswa yang diajarakan dengan model pembelajaran kooperatif tipe pair checks sebesar 69,93 sedangkan rata rata hasil belajar matematika siswa yang diajarkan dengan model pembelajaran klasik sebesar 61,93[8].

Berdasarkan semua data yang telah dijabarkan dapat disimpulkan bahwa model pembelajaran kooperatif tipe pair checks terhadap hasil belajar fisika siswa SMP Negeri Model Terpadu Madani. Melalui model pembelajaran ini siswa dilibatkan untuk aktif dan bekerja berpasangan sama dengan teman sebangkunya, melatih siswa untuk mengecek jawaban teman dan belajar bekerja sama dalam kelomok. Oleh karena itu model pembelajaran kooperatif tipe pair checks dapat dijadikan sebagai salah satu alternatif dalam kegiatan belajar mengajar untuk meningkatkan hasil belajar belajar siswa khususnya pada mata pelajaran fisika.

\section{KESIMPULAN DAN SARAN}

\section{A. Kesimpulan}

Berdasarkan hasil analisis uji hipotesis diperoleh bahwa ada perbedaan hasil belajar fisika siswa antara kelompok yang menggunakan model pembelajaran kooperatif tipe pair checks dengan kelompok yang menggunakan model pembelajaran konvensional pada siswa kelas VIII SMP Negeri Model Terpadu Madani. Hal ini dapat dilihat dari rerata skor posttest. Dan uji-t dua pihak. Rerata skor kelas eksperimen adalah 8,92 sedangkan rerata skor kelas kontrol adalah 7,67. Hasil uji, pada taraf $a=0,05$ diperoleh thitung $>$ tabel atau 2,16>2,02 atau $\mathrm{H}_{0}$ ditolak dan $\mathrm{H}_{1}$ diterima, yang berarti terdapat perbedaan model pembelajaran kooperatif tipe pair checks terhadap hasil belajar fisika siswa, artinya bahwa model pembelajaran tipe pair checks berpengaruh terhadap hasil belajar fisika siswa.

\section{B. Saran}

Berdasarkan hasil yang telah didapatkan pada penelitian ini, maka untuk penelitian selanjutnya diharapkan dapat melakukan penelitian sejenis dengan materi dan lokasi penelitian yang berbeda guna memperoleh hasil yang lebih baik.

\section{DAFTAR PUSTAKA}

[1] T. Gök, \& Sılay. Masalah Teori Khusus Kelompok Koperatif dalam Penelitian pada Metode Pengajaran Pemecahan Masalah. Nasional Sains dan Matematika Kongres Pendidikan, Universitas Marmara , Istanbul. 2004.

[2] Danasasmita, W. Model-Model Pembelajaran Alternatif. Bandung: UPI. 2008.

[3] Nusantari, dkk. "Peningkatan keterampilan belajar biologi melalui model kooperatif tipe pair checks siswa kelas ii smpn 2 gorontalo". Jurnal Pendidikan Dan Pembelajaran, Volume 15, Nomor 1, 2008.

[4] Pamukkale. Effects of Cooperative Learning Method of Pairs Check Technique on Reading Comprehension. Elementary Education Online, 7(3), 748-757, 2008.

[5] L. Lestari, \& S. Linuwih. "Penerapan Model Pembelajaran Kooperatif Tipe Pairs Check Pemecahan Masalah Untuk Meningkatkan Social Skill Siswa". Jurnal Pendidikan Fisika Indonesia, Vol.8, No. 2, hal. 190-194, 2012.

[6] T. Sukran. "Effects of cooperative learning method of pairs check technique on reading comprehension". Jurnal Elementary Education Online, 7(3), 748-75, 2008.

[7] Sugiyono. Metode Penelitian Kuantitatif, Kualitatif, dan $R$ and $D$, Cet. Bandung : Alfabet. 2008.

[8] S. Komara. Pengaruh model pembelajara tipe pair check terhadap hasil belajar matematika siswa. Universitas islam negeri syarif hidayatullah jakarta. 2010. 